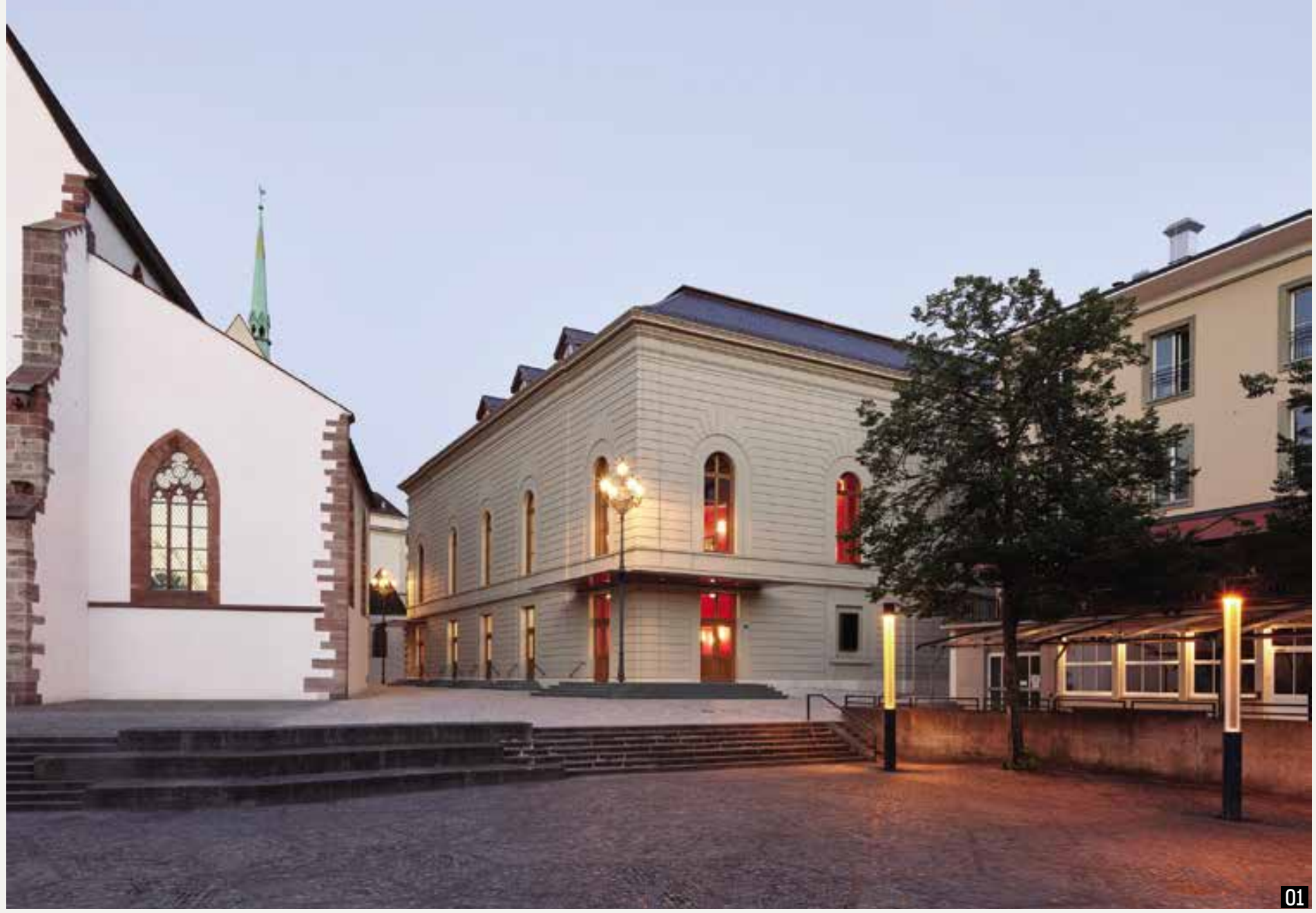

\title{
TÉR-IDŐ ILLÚZIÓK
}

\section{MINTHA EGY ESTERHÁZY-REGÉNYBEN JÁRNÁNK | HERZOG \& DE MEURON:}

STADTCASINO BASEL

_A Herzog \& de Meuron iroda váratlan koncepcióval alakította át a bázeli kaszinó épületét és a város közterét. Az Európa-szerte híres, kitúnő akusztikával rendelkező tizenkilencedik századi koncerttermet egy teljesen új kiszolgáló térsorral bővítették, az új szárny homlokzatait pedig a történeti formákat idéző felületekkel vonták be. Meghökkentő az alakhünek túnő kendőzetlen szerkesztésmód egy olyan irodától, amely az elmúlt közel négy évtizedben a nemzetközi kortárs építészet élharcosa volt. [1] Kísérletező alkotásaik meghatározó erővel alakították az ezredforduló építészeti trendjeit, most mégis alávetnék magukat a konzervatív újhullámnak? Autonóm alkotói logikájuk talán más irányba vezet... De akkor mit is jelent a történetiség Jacques Herzog és Pierre de Meuron számára szülővárosukban, Bázelben?

\section{1}

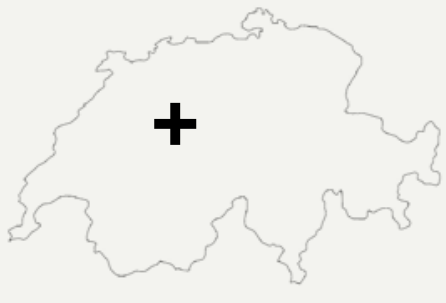





02

ÉPÍTÉSZI

Jacques Herzog, Pierre de Meuron, Andreas Fries
SZERZŐ |

Wettstein Domonkos
_A kérdés megválaszolásához érdemes elolvasni az építészek által megfogalmazott, történeti utalásokban gazdag ismertetést. [2] Mintha egy Esterházy-regényben járnánk: nézőpontról nézőpontra vezetik végig az olvasót a terek sokrétű történetén. A szövegben megidézett múltbeli asszociációk és az épület formai utalásai úgy bánnak a történetiséggel, ahogy Esterházy Péter az irodalomtörténet kánonjait feltörő vendégszövegekkel. Mintha a formabontó klasszicizálás a történelmi hivatkozások végtelen terét nyitná ki. És ahogy Esterházy iróniája, Herzog és de Meuron fantáziája éppúgy a tér-idő kapcsolatokat újraírva űz különös játékot a szemlélő naivitásával.

_A bázeli Stadtcasino átépítése a közvélemény kritikus figyelmétől övezve heves viták közt zajlott az elmúlt másfél évtizedben, ami nem példa nélküli a hagyományosan erős és autonóm polgári társadalommal rendelkező országban. A 19. század folyamán a városi erődítmények elbontását követően több rétegben épült át a Svájc északi határán fekvő kereskedőváros. A ma már múzeumként működő domonkos rendi kolostortemplom mellől elbontották a környező épületeket, és ezzel - ahogy ezt a Herzog $\delta$ de Mueron iroda is hangsúlyozza - új kulturális életnek nyitottak teret a Barfüsserplatzon. I826-ban készült el a kaszinó, majd a Blömlein Színház, a század második felében pedig Johann Jakob Stehlin neobarokk stílusban tervezett épületei folytatták a kulturális központ kiépítését. Ezek közé tartozott a mücsarnok, a színház és a szobrászati kiállítótér. A Musiksaal, azaz a koncertterem I876-ban készült el Stehlin tervei szerint. A mellette álló kaszinót I939-ben lebontották, és a Kehlstadt $\&$ Brodtbeck építészpáros tervei szerint új formában építették fel. Az új épület összeépült a koncertteremmel, a közös bejárattal a kiszolgálófunkciókban szerény Musiksaalt is kisegítette. A kulturális építkezések sora azonban nemsokára megtört, a városi színházat pedig elbontották, és ez - Herzog $\delta$ de Meuron értékelése szerint - szimbolikusan a kulturális projekt befejezését jelentette. [3] Az eredeti épületek közül csak a mücsarnokot, a kiállítóteret és a Musiksaalt őrizték 


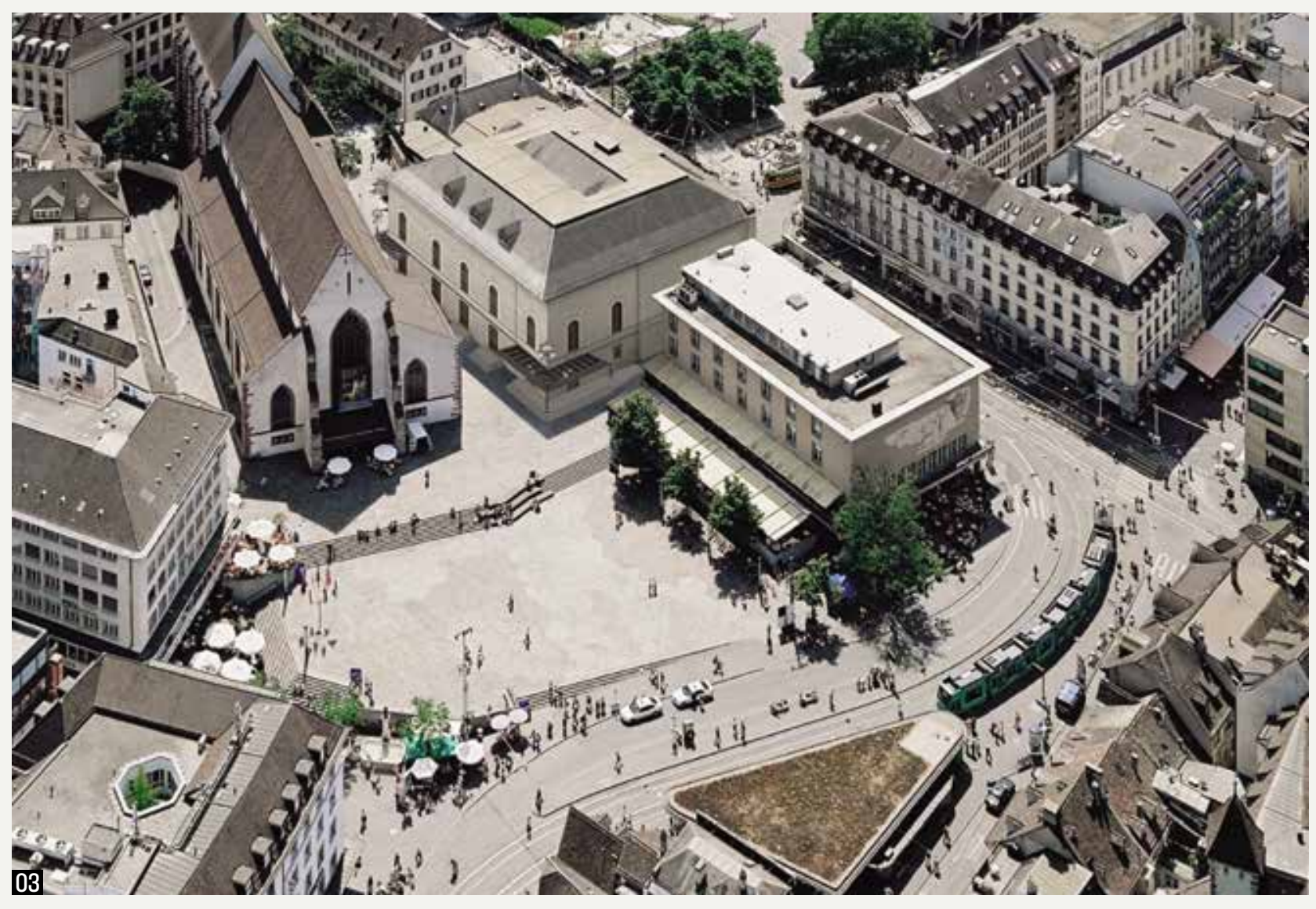

\section{A Barfüsserplatz új palazzója \\ 04 A lépcsőház áramló terét lyoni brokáttapétával vonták be 05 A kibővített Musiksaal alaprajzai}

meg. Az I40o fó befogadására alkalmas Musiksaal ad otthont a Bázeli Szimfonikus Zenekarnak, és mint az egyik legrégebbi koncertterem, évről évre számos rangos hangversenyt fogad be.

_ Az egyik legidősebb, kiváló akusztikával bíró koncerttermet az ezredfordulót követően szerették volna a jelenkor igényeihez és követelményeihez alkalmazkodóan bővíteni. Az eredeti formában megőrzött terem köré új fogadóés kiszolgálótereket kívánt a korszerü üzemeltetés. Az I939-ben épült kaszinó helyére tervpályázatot írtak ki, amit Zaha Hadid irodája nyert meg. [4] Az időközben tragikusan korán elhunyt világhírü iráni építész designer nő nem hazudtolta meg önmagát, amikor Bázel óvárosába egy nagyvonalú, áramló formába öntötte épülettervét. A köztér felett ellebegő hullámzó épületet transzparens üvegfelületek burkolták. A felület közepén egy nagy tölcsérszerü megnyitás hasította át a formát. A leírtakból talán érezhető, Zaha Hadid szétfeszítette a középkori eredetű óváros történeti kereteit, ám amit a kőanyag talán elviselt volna, azt a helyi polgárság közízlése már nem bírta el. A tiltakozások nyomán 2007-ben népszavazásra bocsátották a tervet, ahol 62,2\%-kal elutasították a megvalósítását. [5] Az építészeti kérdések népszavazásra bocsátása egyáltalán nem példa nélküli Svájcban. A bázisdemokráciára épülő országban nagy tere van az alulról jövő kezdeményezéseknek és az autonóm polgári gondolkodásnak. Az építészet közügy, és ezt valóban meg is élik. A soknyelvű, széttagolt ország nehéz alpesi terepén az építés kultúrája vált közös nevezővé. Náluk nem „nyelvében él a nemzet”, hisz több ezer dialektusban beszélik az egyes nyelveket is, hanem az építésben. Az ország egy folyamatos építkezés, akár a hegyvidék mütárgyairól, út- és vasútvonalairól, akár a városok folyamatos fejlődéséről legyen szó. És ebben az építkezésben az ország polgárai aktívan részt vesznek, véleményt nyilvánítanak, végül pedig szavaznak.

_Ezt követően került képbe a bázeli székhelyű, ugyanakkor világhírű Herzog de Meuron iroda. Ne felejtsük, hogy ez az egyszerre lokális, ugyanakkor globális kettős identitás korábban már többször megmutatkozott a tervezőpáros kritikai alapállásában. [6] Projektjeikkel nemcsak az ország látképét, de a társadalom terét is karakteresen formálták. [7] 20I2-ben felkérést kaptak egy tanulmányterv elkészítésére: hogyan lehet korlátozott térbeli lehetőségek közt a Musiksaalhoz kapcsolódó kiszolgálótereket úgy átszervezni, hogy azok a mai követelményeknek is megfelelő színvonalon szolgálhassák ki a vendégeket? Az iroda megfogalmazása szerint kezdetben a templom és a koncertterem közötti területre összpontosítottak, ahol már korábban is kolostorok álltak, azonban hamar rájöttek, hogy városépítészeti szempontból nem ez a megfelelő megoldás. A kortárs építészeti beavatkozások valamiféle „patchwork”-ként hatottak a történeti térben, amely szükségszerủen kitakarja az új épületszárny mögé szoruló Musiksaalt. A koncertterem egyre inkább „autonóm” épületként jelent meg számukra, amelyet az I939-ben épült és korábban bontani kívánt kaszinótól függetlenül kellett 

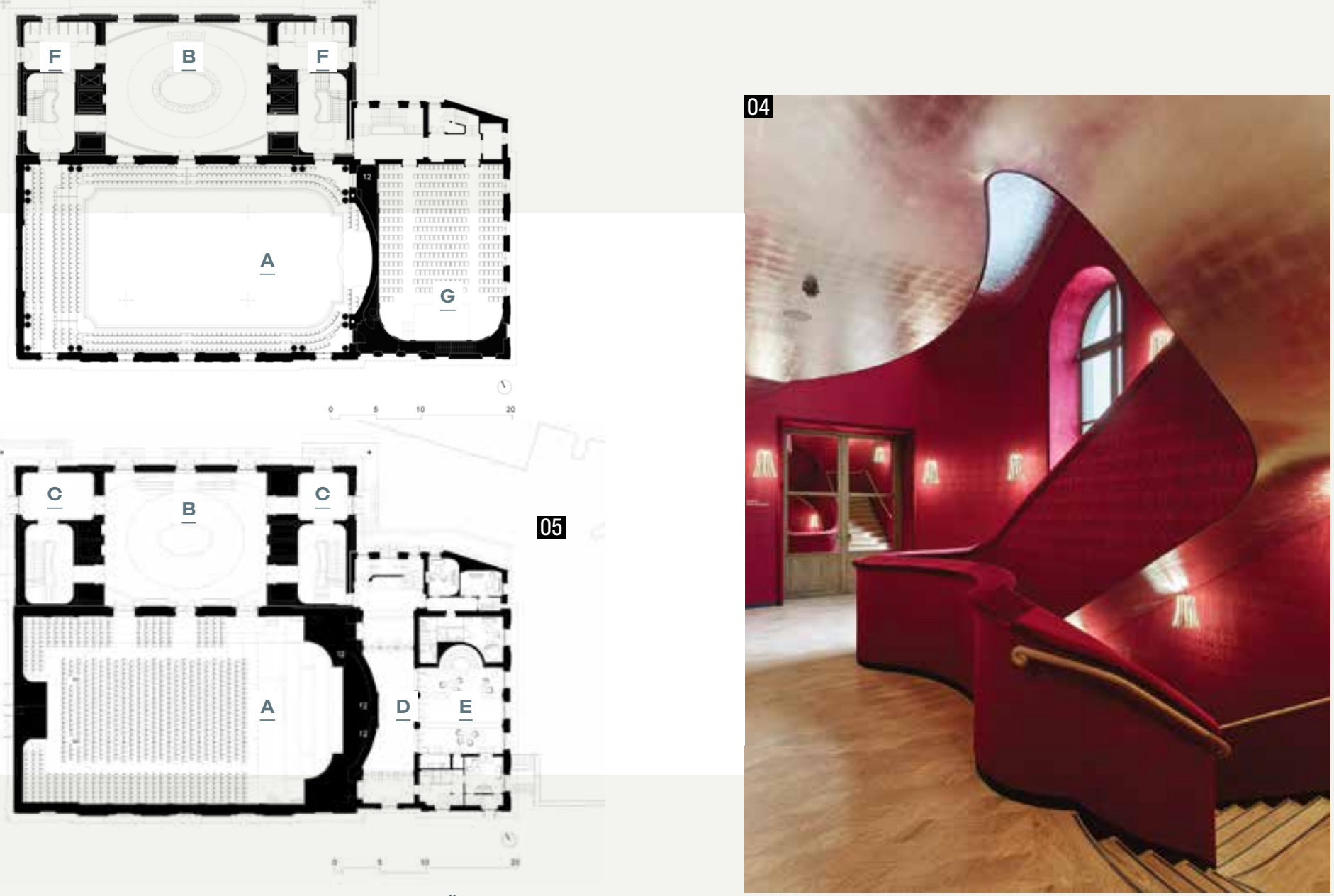

\begin{tabular}{l|ll|l} 
A & Musiksaal & E & Öltözők és hangolószobák \\
B & Újfoyer & F & Ruhatár \\
C & Előtér & G & Hans Huber-terem \\
D & Múvészbejáró & &
\end{tabular}

kezelniük. Ezzel előállt számukra egy „palazzo” forma, amely a városi térben szoliter tömegként önálló entitással 05 van jelen. Az új terek a régi épületrész szerves folytatása- 02 ként nőttek ki, körülfonva a neobarokk koncerttermet. Az új épületrész burkához a Stehlin-féle történeti homlokzatokat vették alapul. Digitális eszközökkel beszkennelték az eddig elrejtett belső homlokzati felületeket, és ezeket vetítették rá az új külső falfelületekre. Ezzel sosemvolt helyzetekben jelentek meg a Stehlin-féle neobarokk felületek. _A formabontó rekonstrukció a szerkezeti megoldásban is az ellentmondásokat kerülgetve jelenik meg. A modern technológiáknak megfelelően az épület vasbeton teherhordó falszerkezetére hőszigetelés és gépészeti szerelvényezés került, majd az átszellőztetett légrést követően szerelték fel a homlokzati paneleket. A kőburkolatot imitáló panelek festett faelemekből készültek. Herzog $\&$ de Meuron szerint ez is egyfajta visszautalás a történeti épület tizenkilencedik században alkalmazott festett faszerkezeteire. Az eredeti épületben a szűkös pénzügyi lehetőségek miatt a kőburkolatok imitálására több helyen is alkalmazták a festett faelemeket. Jellemzően a robusztus párkányokat is könnyű faszerkezetből építették már százötven évvel ezelőtt is. A belső térben az oszlopokat fából és gipszből alakították ki, ebben az esetben a financiális kérdések mellett az akusztikára is tekintettel voltak a régmúlt idők mesterei. A jelen építészei ugyanakkor nem követték alakhü pontossággal a klasszikus geometriákat, de - igaz, csak kismértékben a technológiához és az anyag szerkezeti követelményeihez igazították azokat, ezzel pedig torzult a stílushű projekció következetessége. De valójában nem is a milliméterpontos alakhü idézés volt a céljuk. Tervük nem rekonstrukció, hanem játék a térrel és az idővel.

_Ez a tér-idő játék a város közterein is folytatódik.

A kaszinó és a Musiksaal közös bejáratát adó összeköttetést elbontották, az elváló épületek közt ezzel egy új közterületi kapcsolat alakult ki. A városépítészeti gesztus új helyzetbe hozza az épületek bejáratait, és a többirányú megközelítést is lehetővé teszi. Mindez az 1939-es Stadtcasino felépültét megelőző állapotot idézi vissza. A nyitás azonban nem áll meg a Musiksaal kérdésénél, és továbbgyűrűzik a Barfüsserplatz megújításának dilemmájára. A tervezők szerint a helyzet egyértelműen rávilágít az 1939-es Stadtcasino téves pozicionálására, mivel az „most hátat fordít a köztérnek, miközben a pezsgő közteret egy forgalmas villamosmegálló szeli ketté”. Herzogék az első mozdulatot már megtették, hogy a város kulturális központja visszanyerje eredeti rangját a polgárok hétköznapjaiban. Kérdés, partnerek lesznek-e ebben a történelmi a játékban?

_A Herzog $\delta$ de Meuron által összeállított projektdokumentációban a külső homlokzatokról nem szerepelnek képek. A tervezők a belső tér kialakítását helyezik az alkotói fókuszba, igaz, a külső homlokzat inverze a belső térben is megjelenik. Míg a külső felületeken - talán a Zaha Hadidprojekt elutasítására is reflektálva - lemondtak a szuverén alkotói önkifejezés lehetőségéről, vagy legalábbis történeti 


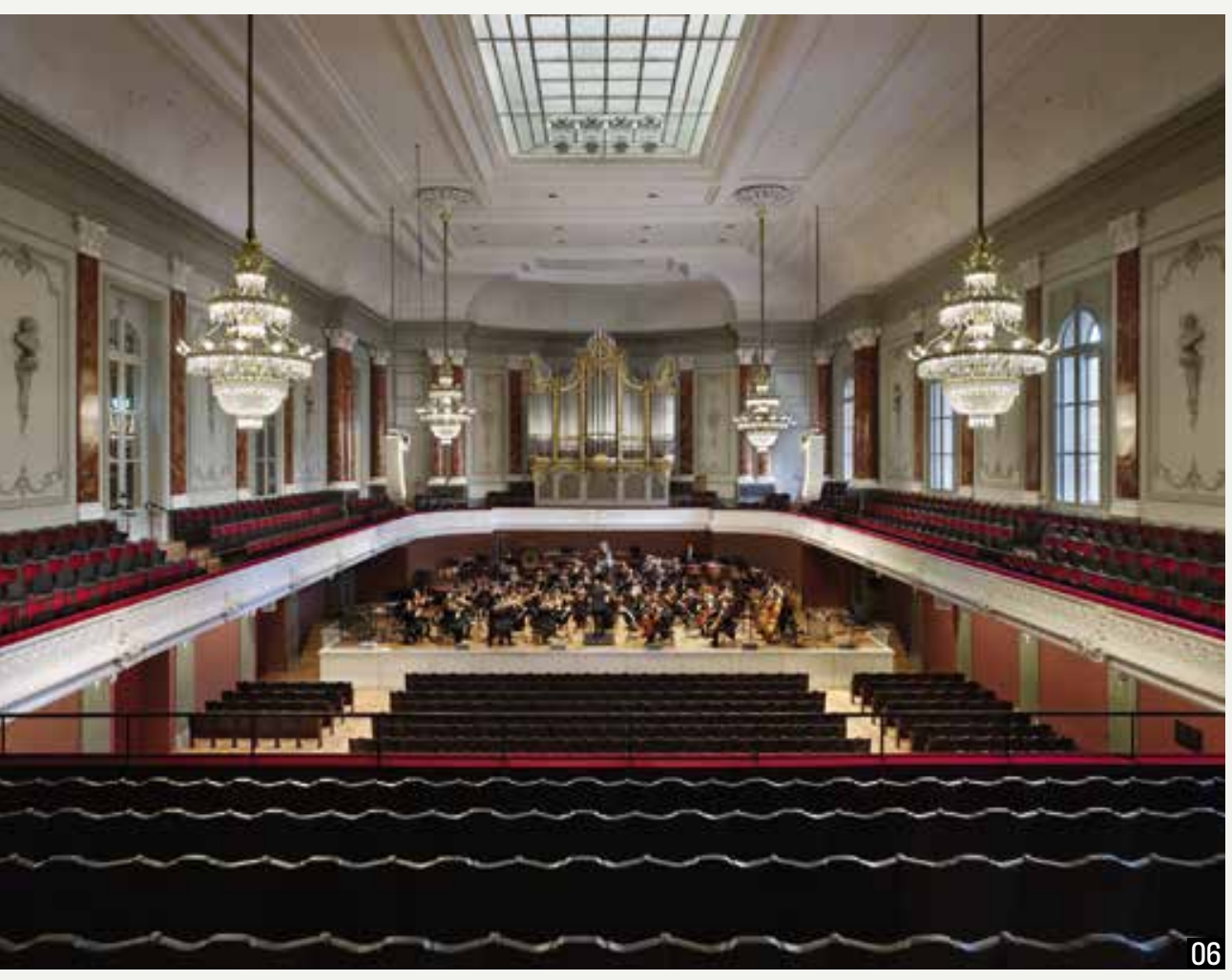

\section{„Azépitészpáros ironikus} gesztusként forgatja ki a múltba forduló közizlést, miközben a tér-idö összefüggéseket feloldva teljes értékü alkotásként irja újra a város történetét"

kosztümöket öltöttek magukra, a belső térben már annál autentikusabban jelennek meg az iroda kísérletező szemléletét tükröző anyagok és formák. Igaz, a belső tér sem szakad el radikálisan a történeti előzményektől, inkább csak feloldja és képlékeny alapanyagként formálja újra a klaszszicizáló tereket. Az I876-ban épült híres koncerttermet, melyet 1905-ben Stehlin által jelentősen átépítettek és orgonával egészítették ki, most az I905-ös állapotnak megfelelően rekonstruálták építészettörténész és müemlékvédelmi 07 szakértők bevonásával. Az új foyer-ből a koncertterem és a kamaraterem is egyaránt közvetlenül elérhető. A kétszintes teret egy nagy födémmegnyitás kapcsolja össze, miközben a födémek íves vonalvezetésű szélei ellebegnek a külső falaktól. A belső téri koncepcióban különös jelentőséggel formálták meg a lépcsőket, amelyek az előadások közti szünetekben a társasági élet pezsgő tereivé válnak. Pulzáló kialakításuk az egész épület dinamikáját meghatározza. A térbeli illúziók fokozásához a tervezők a I9. század jellegzetes anyaghasználatát, szín- és formavilágát gondolták újra, szürreális módon átértelmezve. Jó példa erre a tükrök alkalmazása a foyer-ben, amelyek kedvelt belsőépítészeti elemei voltak az I80o-as éveknek. Most azonban az anyag totalitásában, a végfalakon és a mennyezeten teljes felületeken alkalmazzák, ezzel egyszerre tágítva a térbeli és történelmi reflexiókat. A kristálycsillárok szintén térben és időben is visszatérő elemei a belső térnek, igaz, szerepüket LED-technológiával formálták újra. Az utalások pedig a részletek szintjén is egészen mélyre hatolnak. A lépcsőház falát borító brokáttapétát attól a lyoni manufaktúrától rendelték meg, amely a koncertterem megnyitása előtti évben az Opéra Garnier számára szállította ugyanezt a mintát. A mintázatot a padló rombusz mintázatú parkettája is tükrözi, miközben a rakásirány a koncertterem halszálkás parkettáját is követi.

_ De mielőtt párhuzamokat keresnénk a konzervatív építészet egyre erősebb rekonstrukciós hullámaival, érdemes újra feltenni a kérdést, mit is jelent az új klasszicizálás ebben a kontextusban. Svájc szikár modern építészetéről ismert, ugyanakkor az elmúlt évtizedben Adam Caruso zürichi szerepvállalása révén a klasszicizáló formák is megjelentek az országban. [8] A Herzog \& de Meuron páros talán ezekre a tendenciákra is reflektál sajátos logikájával. A Stadtcasino történeti formái mögött egyértelműen felsejlik az alkotói pályájuk kezdetétől jellemző poétikus, ugyanakkor kísérletező felületkezelés és anyaghasználat. Egész életmüvükre nagy hatással volt a német performansz képzőművész Joseph Beuys, akinek kritikai alapállása leginkább a szélsőséges anyagtársításokban jelenik meg. [9] Herzogék ezt a konfrontatív gondolkodást emelték át az építészetükbe, miközben az aktuális építészeti trendeket rendre felhasználták, pontosabban kiforgatták. Egyik korai munkájuk, az 1985-ös Casa de Piedra Tavoléban [Io] látszólag egy hagyományos kőfalazatú ház, amely a nyolcvanas évek regionális áramlataihoz is besorolható lenne, miközben az épület minden részletében kiélezi a tektonika és az anyagszerüség ellentmondásait. De ugyanez a kritikai, kissé ironikus alapállás jellemzi későbbi nagyobb projektjeiket is, a bázeli Schaulager illuzionisztikus tereit, a pekingi madárfészek stadion szimbolikusan robusztus acélfonatát, a madridi Caixa Forum földtől ellebegtetett történeti gyárépületét, vagy épp a Bázelben tavaly átadott és sokat vitatott Meret Oppenheim toronyház esetlenül átlyukasztott tömegét. Mindegyik projekten tükröződnek az adott korszak építészetének nemzetközi hullámai, sőt, az iróniát csak fokozza, hogy formai gesztusaikkal meghatározó hatással voltak az ezredforduló építészetére anélkül, hogy konfrontatív, kritikai szándékaikat megértették volna. A bázeli Stadtcasino esetében sincs ez másképp. Az építészpáros ironikus gesztusként forgatja ki a múltba forduló közízlést, miközben a tér-idő összefüggéseket feloldva teljes értékű alkotásként írja újra a város történetét. Mintha csak egy Esterházy-szöveget olvasnánk: „Vagyis mindig az egészről van szó, és nem a szavak felosztogatásáról szalonképesekre és szalonképtelenekre.” [II] 
Az 1905-ös állapotában rekonstruált koncertterem Reflexív falfelületek az új foyer-ban

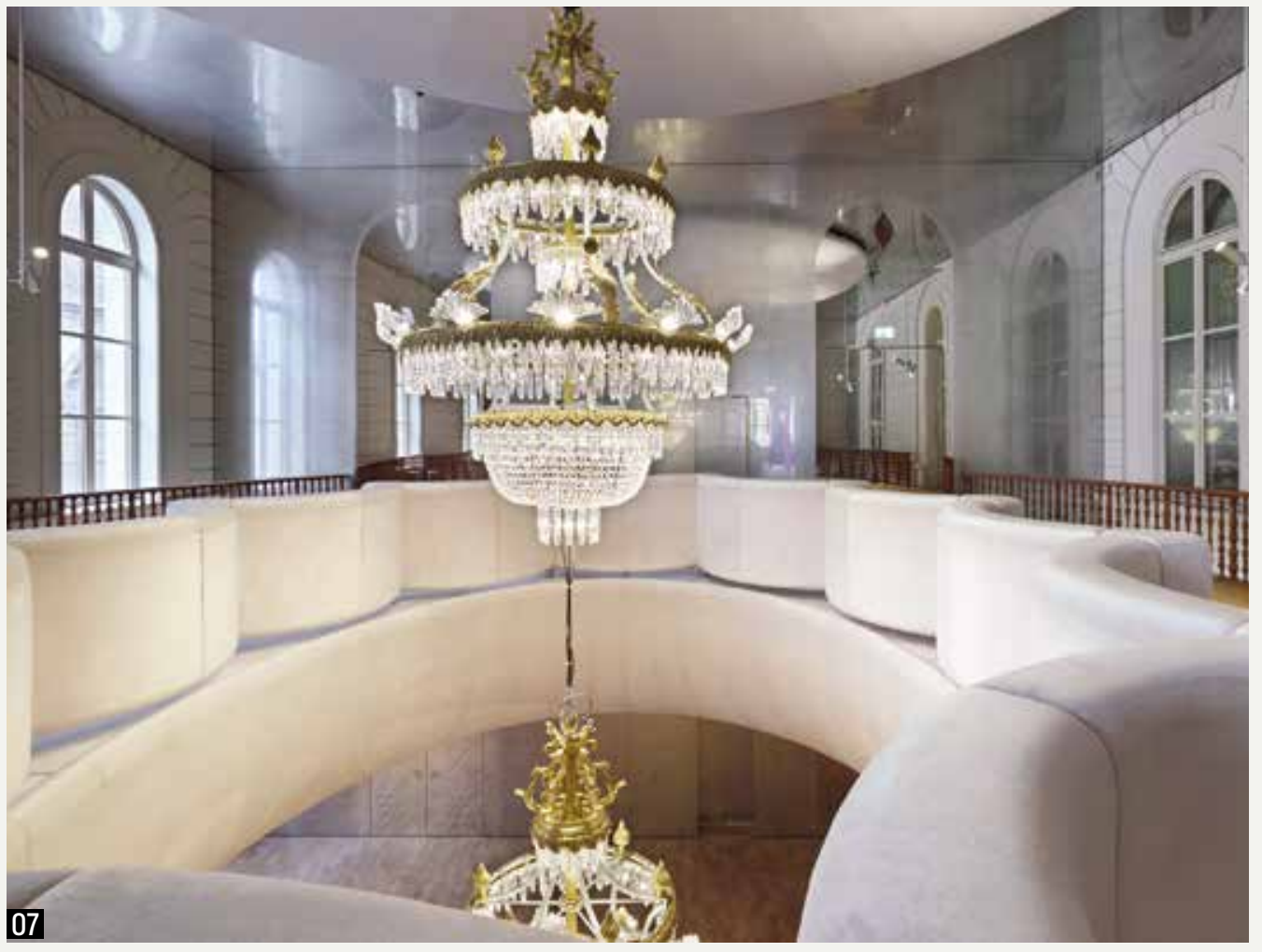

ÉPÍTÉSZ MUNKATÁRSAK: Thorsten Kemper, Michael Schmidt, Stephan Weber, Inga Federe | GÉPÉSZET: Waldhauser+Hermann AG, Münchenstein | STATIKA: A. Aegerter \& Dr. 0. Bosshardt AG, Basel I LÉGTECHNIKA: Waldhauser+Hermann AG, Münchenstein | ELEKTROMOSSÁG: Pro Engineering AG, Basel | KIVITELEZÉS: Ritter Giger Schmid Architekten SIA AG, Basel | FOTÓK: KÜLSŐ KÉP: Stadtcasino Basel, Roman Weyeneth | BELSŐ KÉPEK: Ruedi Walti | RAJZOK, MADÁRPERSPEKTÍVA: HerZog \& de Meuron

\section{IRODALOM / REFERENCES}

[1] Kovács, Dániel: „Ez a homlokzat 2020-as, a Herzog de Meuron tervezte”, Építészfórum, 2020-07-28, hozzáférhető: <https://epiteszforum.hu/ez-ahomlokzat-2020-as-es-a-herzog-de-meuron-tervezte> [utolsó belépés: 2020-09-10].

[2] Herzog, Jacques - De Meuron, Pierre: „Stadtcasino, Basel, Herzog \& de Meuron, Basel, 2020”, hozzáférhető: <https://www.herzogdemeuron.com/index/ projects/complete-works/401-425/402-extension-of-the-stadtcasino-basel.html> [utolsó belépés: 2020-09-10].

[3] Herzog \& de Meuron: „Stadtcasino, Basel”, Afasiaarchzine, 2020-06-20, hozzáférhető: <https://afasiaarchzine.com/2020/06/herzog-de-meuronstadtcasino-basel/> [utolsó belépés: 2020-09-10].

[4] Hadid, Zaha: „Neues Stadt-Casino, Basel”, hozzáférhető: <https://www.zaha-hadid.com/architecture/neues-stadt-casino/> [utolsó belépés: 2020-09-10].

[5] Fairs, Marcus: „Basel rejects Zaha Hadid casino”, Dezeen, 2007-06-25, hozzáférhető: <https://www.dezeen.com/2007/06/25/basel-rejects-zaha-hadidcasino/> [utolsó belépés: 2020-09-10].

[6] Diener, Roger - Herzog, Jacques - Meili, Marcel - De Meuron, Pierre - Schmid, Christian: Switzerland - an Urban Portrait, Walter de Gruyter, Basel 2013.

[7] Wettstein, Domonkos: „Eltérő pozícióból - Urbanizáció és autonómia ellentmondásai Svájcban - az ETH Studio Basel és Gion A Caminada vitája alapján”, Utóirat: A Régi-Új Magyar Épitőmúvészet Melléklete, Vol 12, № 3 (2012), pp 22-27.

[8] Wettstein, Domonkos: „Adam Caruso érzelmes vallomása Zürichhez - A brit klasszicizálás és a svájci modernitás találkozása az Europaallee-n”, Metszet, Vol 9, No 4 (2018), pp 20-25.

[9] Mesch, Claudia: Joseph Beuys (Critical Lives), Reaktion Books, London 2017.

[10] Mack, Gerhard: Herzog \& de Meuron 1978-1996, Vol 1-3, Birkhäuser, Basel 2018.

[11] Esterházy, Péter: „A szavak csodálatos életéből”, Digitális Irodalmi Akadémia, Petőfi Irodalmi Múzeum, Budapest 2011, hozzáférhető: <https://reader.dia. hu/document/Esterhazy_Peter-A_szavak_csodalatos_eletebol-395> [utolsó belépés: 2020-09-10]. 


\title{
ABSTRACTS
}

\author{
ARNÓTH, Ádám: INTERNAL WEALTH \\ Citation: Metszet, Vol 11, No 5 (2020), pp 18-25, DOI: 10.33268/Met.2020.5.1
}

SYNAGOGUE RESTORATION, BUDAPEST, HUNGARY | Restoration Architect: Tamás KöNIG DLA and Péter WAGNER DLA

Originally designed in the Moorish Revival style by Otto Wagner in 1873, this synagogue served as a place of worship for the more conservative members of Budapest's Jewish community. WWII damage left the building

\author{
in a ruinous state, although repairs to the \\ structure did occur, restoration in earnest did \\ not start until 2007. The subsequent works \\ have restored this place of worship to its \\ former splendor and function. Attention payed
}

to the original design, the Torah Ark and unusual use of Moorish decorative elements have helped demonstrate why this building is one of Budapest's significant historic monuments.

\section{LÉVAI, Tamás: TIME TRAVEL}

Citation: Metszet, Vol 11, No 5 (2020), pp 26-31, DOI: 10.33268/Met.2020.5.2

PJ VILLA, KOLOZSVÁR (CLUJ-NAPOCA), ROMANIA | Architect: Miklós PÉTERFFY

Originally designed in 1937, an amazingly exciting period for architecture any where, this family home has recently been modernized.

Or has it been restored to its intended form, with updated technology, use of space and materials. Division of spaces has been achieved by feats of geometry on a grand scale, with curved walls and high ceilings developing a perfectionist feeling drawing inspiration from the 1930s desire for luxury. A possible destination for architectural tourism for those departing from Budapest.

\section{CSANÁDY, Pál: MILITARY LEGACY}

Citation: Metszet, Vol 11, No 5 (2020), pp 32-37, DOI: 10.33268/Met.2020.5.3

LMCC ARTS CENTER, GOVERNORS ISLAND, NEW YORK, USA | Restoration Architect: Jay L. BERMAN

A former military base has seen a nineteenthcentury munitions warehouse converted into

a venue for the arts by the I ower Manhattan spaces for temporary exhibitions, studio spaces and public events. As one of the few areen nark areas of New York this offers leisure time activities. The key to this project's success being the fact that a minimum level of work was reauired due to the architectural

\section{WETTSTEIN, Domonkos: SPACE-TIME ILLUSION}

Citation: Metszet, Vol 11, No 5 (2020), pp 38-43, DOI: 10.33268/Met.2020.5.4

STADT CASINO, BASEL, SWITZERLAND | Architects: HERZOG and DE MEURON

The designers of this project have taken an approach similar to that of an Eszterházy novel: travelling through a multifaceted history of spaces from point of view to point of view. This might be an act of fantasy or irony resulting in a restoration of neobaroque elements, insertion of contemporary interventions, resulting in maintaining the original acoustic quality of the concert hall and improved non-performance circulation areas: foyer, stairwells and corridors which now create a new sequential flow throughout the building complex.

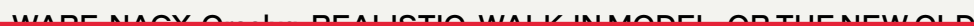

Citation: Metszet, Vol II, No b (2020), pp 44-49, DOI: 10.33268/Met.2020.5.5

RESTORATION OF THE HORSE RIDING-HALL, BUDAPEST, HUNGARY | Restoration Architects: Ferenc POTZNER

A key element of the National Hauszmann project to restore or rebuild monumental buildings in Budapest's Castle District includes this Riding-Hall damaged in WWII and finally demolished in the 1950s. Obviously when a building is totally demolished rebuilding to original plans will not occur due to changes in materials, construction methods or statutory requirements. The question arising being that of "is this a faithful reconstruction or a full-scale architectural model" erected in an attempt to satisfy grandiose plans or a false sense of history?

\section{CSONTOS, Györgyi - TÓTH, Timea: ENLIGHTENMENT}

Citation: Metszet, Vol 11, No 5 (2020), pp 50-57, DOI: 10.33268/Met.2020.5.6

CHURCH OF THE STIGMATIZATION OF SAINT FRANCIS, BUDAPEST, HUNGARY | Restoration Architects: Judit Z. HALMÁGYI and Tamás TÓTH

Often religious buildings fall into a state of neglect, here a Roman Catholic Church suffered from a combination of problems: being part of a none too sympathetic urban composition and neglect due to dissolution during the communist era. The architects responsible for the restoration started by making a full digital survey of the building from which analysis of required works could be implemented. Improvements to the

\section{DOMBÓVÁRI, János: REPAIRED FINALE}

Citation: Metszet, Vol 11, No 5 (2020), pp 58-63, DOI: 10.33268/Met.2020.5.7

HARD ROCK HOTEL, BUDAPEST, HUNGARY Architects: László SZÁSZ and Erzsébet HAJNÁDY

Following the established business model of the Hard Rock company design concepts are handled by their local franchise partner. Here the decision was made to respect the existing building's elevations, whilst adding a three storey high golden crown that responds to the location, Nagymezó Utca's, Broadway like ambitions. To lift a corner site architecturally building's fabric, quality of lighting and its place in the urban context have been vastly improved upon. with a bold, traditionally, out of context statement. This approach completes the problem of a poorly massed streetscape whilst adding a taste of Rock ' $n$ ' Roll rebellion. 